\title{
Klimakrisens muligheter
}

Året 2016 ga vår klode flere bekymringsfulle klimarekorder: Det ble det varmeste som noen gang er registrert, nivået av $\mathrm{CO}_{2} \mathrm{i}$ atmosfæren nådde nye rekorder og havnivåene har aldri vært høyere (1).

Nå viser nye tall fra World Meteorological Organization (WMO) at ekstremene fortsetter (1). I februar 2017 ble det bare i USA satt eller tangert over 11000 varmerekorder, samtidig som Nord-Afrika og den arabiske halvøy hadde uvanlig kulde. Andelen $\mathrm{CO}_{2} \mathrm{i}$ atmosfæren fortsetter å øke. Og vinteren i Arktis har vært preget av varmt og fuktig vær, mens mengden sjøis i Antarktis aldri har vært mindre (1). Utviklingen «utfordrer grensene for vår forståelse av klimasystemene. Vi er nå i virkelig ukjent terreng», uttalte David Carlson, direktør for WMOs klimaforskningsprogram (2).

Helsekonsekvensene av klimaendringene blir tydeligere og tydeligere. Globale helseutfordringer som for bare få år siden var «mulige» og «fremtidige», er blitt reelle (3). Ekstrem tørke og flom driver millioner på flukt og skaper matmangel, epidemier og mangel på elementære helsetjenester. Situasjonen er særlig desperat øst i Afrika, der ekstrem og langvarig tørke kombinert med krig og ustabile politiske forhold har skapt det FNs sjef for nødhjelp har kalt «den største humanitære krisen siden 1945» (4). Og de akselererende klimaendringene vil kunne gjøre situasjonen verre $i$ årene som kommer. UNICEF har beregnet at så mange som 600 millioner barn - ett av fire barn på kloden - vil leve i områder uten tilstrekkelig tilgang på vann i 2040 dersom ikke verdenssamfunnet tar kollektivt ansvar (5). WHO forventer 250000 dødsfall årlig i perioden 2030-50 på grunn av klimaassosiert underernæring, malaria, diareer og vannmangel (6). Og nettopp effekten på helse og stabilitet $\mathrm{i}$ utviklingslandene er det som har fått Verdens økonomiske forum til å utrope klimaendringene til den største trusselen mot global stabilitet (6).

Paris-avtalen er så langt verdenssamfunnets tydeligste svar på utfordringene (3). Avtalen trådte i kraft i november 2016. Dette er den første klimaavtalen som er rettslig bindende og reelt forpliktende for alle land (7). Men det gjenstår mye arbeid før avtalen er operativ. I løpet av 2017 skal det konkrete regelverket utarbeides, det gjelder blant annet nasjonale utslippsmål, finansiering, rapportering og tilpasning i de enkelte land (7).

Klimaendringene kan for mange ennå fortone seg som fjerne og uhåndgripelige. Men helseutfordringene knyttet til et klima i rask endring er håndgripelige realiteter allerede nå. Det reflekteres også i flere multinasjonale initiativer for å takle de helseproblemene som kommer i kjølvannet av klimaendringene $(8,9)$. For de virkemidlene som kan gi mindre markante klimaendringer, kan også gi bedre helse: Eksempelvis vil lavere bruk av fossilt brennstoff ha betydelige positive helseeffekter. Kull står for $40 \%$ av verdens produksjon av elektrisitet og bidrar til over halvparten av verdens luftforurensning (9). Overgang til renere energikilder vil ikke bare gi lavere $\mathrm{CO}_{2}$ utslipp, men også ha betydelige helseeffekter grunnet reduksjon av blant annet hjerte- og lungesykdommer (9). Bremsing i bruken av fossilt drivstoff og overgang til mer aktive former for persontransport vil på samme måte bidra til mindre livsstilssykdommer. Klimatiltak som høyere forbruk av plantebasert næring kan også forventes å gi substansielle positive helsegevinster (10). Hvis klimaendringene blir mindre enn fryktet, vil det kunne frigjøre ressurser for utviklingsland - til bruk i investeringer for bedre helse $(3,6)$.

En operativ Paris-avtale innen 2018 er et viktig skritt på veien til å minimere klimaendringene. Men kamp mot endringene er også en investering i bedret global helse. I 2015 kalte The Lancets kommisjon en vellykket håndtering av klimaendringene «den største globale muligheten for bedre helse i dette århundret» (11). Slik sett utgjør ikke klimaendringene bare en trussel. De er også en mulighet.

\section{Litteratur}

1. Climate breaks multiple records in 2016, with global impacts. World Meteorological Organization 21.3.2017. Press release Number 04/2017. https://public.wmo.int/en/media/press-release/climate-breaks-multiplerecords-2016-global-impacts (27.3.2017).

2. Carrington D. Record-breaking climate change pushes world into uncharted territory'. The Guardian 21.3.2017. https://www.theguardian.com/environment/ 2017/mar/21/record-breaking-climate-change-world-uncharted-territory (27.3.2017).

3. Brean A. Når pasienten er jorden. Tidsskr Nor Legeforen 2015; 135: 2015.

4. Braaten MFN. Står overfor vår største humanitære krise siden 1945. VG 11.3.2017. http://www.vg.no/nyheter/utenriks/fn/fn-staar-overfor-vaarstoerste-humanitaere-krise-siden-1945/a/23946868/ (27.3.2017).

5. «Nothing can grow without water, » warns UNICEF as 600 million children could face extreme shortages. UN News Center 22.3.2017. http://www.un.org/apps/ news/story.asp?NewsID=56400\#.WNkbPdKa1GE (27.3.2017).

6. Gupta V, Mason-Sharma A, Caty SN et al. Adapting global health aid in the face of climate change. Lancet Glob Health 2017; 5: e133-4.

7. Parisavtalen - en ny global klimaavtale. Regjeringen 29.12.2016. https://www.regjeringen.no/no/tema/klima-og-miljo/klima/internasjonaleklimaforhandlinger/innsiktsartikler-klimaforhandlinger/forhandlingene-om ny-klimaavtale-i-paris/id2457656/ (27.3.2017)

8. Global conference sets health action agenda for the implementation of the Paris Agreement. WHO Conference Conclusions. 8.7.2016. http://www.who.int/ globalchange/conferences/second-global/conclusions/en/ 27.3.2017.

9. Watts N, Adger WN, Ayeb-Karlsson S et al. The Lancet Countdown: tracking progress on health and climate change. Lancet 2017; 389: 1151-64.

10. Haines A, Dora C. How the low carbon economy can improve health. BMJ 2012; 344: e1018.

11. Watts N, Adger WN, Agnolucci P et al. Health and climate change: policy responses to protect public health. Lancet 2015; 386: 1861-914. 